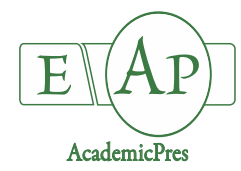

Kyrbassova EA et al. (2020)

Notulae Botanicae Horti Agrobotanici Cluj-Napoca 48(3):1473-1482

DOI: $10.15835 /$ nbha48311991

Research Article

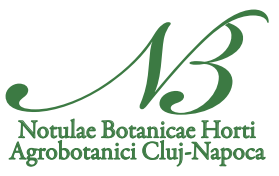

\title{
Anatomical, morphological and phytochemical properties of Aegopodium alpestre Ledeb.: a case study of Kazakhstan
}

\author{
Elzira A. KYRBASSOVA ${ }^{1 *}$, Akmaral A. SARTAYEVA ${ }^{1}$, \\ Elmira M. IMANOVA ${ }^{1}$, Nurdana N. SALYBEKOVA², Gulraikhan E. \\ ZHANTEYEVA 3 , Sholpan S. SHYNYBEKOVA 4 , \\ Kuralay A. ASKARBAYEVA ${ }^{1}$
}

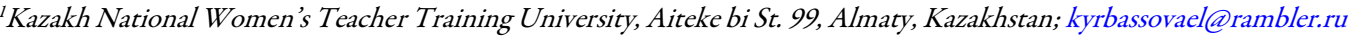 \\ (*correspondingauthor); sartayevaakm@rambler.ru; imanovaelm@rambler.ru; askarbayevakur@rambler.ru \\ ${ }^{2}$ Khoja Akhmet Yassawi International Kazakh-Turkish University, 29 BekzatSattarkhanov Avenue, Turkestan, \\ Kazakhstan; salybekovanur@rambler.ru \\ ${ }^{3}$ T.K. Zhurgenov Kazakh National Academy of Arts, Panfilov St.127, Almaty, Kazakhstan; zhanteyevagul@rambler.ru \\ ${ }^{4}$ Abai Kazakh National Pedagogical University, Dostyk Avenue 13, Almaty, Kazakhstan; shynybekovashop@rambler.ru
}

\begin{abstract}
This article deals with the phytochemical, morphological and anatomical investigation of ethanol-based extracts derived from the leaves and stems of the Aegopodium alpestre. The vegetative organs of $A$. alpestre were conserved according to Strasburger-Fle $\mu$ ming method using a 1:1:1 mixture of alcohol-glycerin-water. A total of 1200 ethanol-based extracts ( 2 from leaves and 2 from stem tissues per plant) were prepared using the Soxhlet extractor. All extracts were used to identify organic and inorganic compounds in the leaves and stems of the studied plant. Contents of biologically active substances, microelements, vitamins and amino acids were determined. This article is the first paper to display very high concentration and diversity of vitamins ( 6 types), micronutrients ( 5 types), and aminoacids (13 types) in the leaves and steams of $A$. alpestre. Findings conclude that identification of biologically active substances in the above the ground vegetative organs of $A$. alpestre may be a common practice in the future. Considering the study results, $A$. alpestre may be used as a medicinal plant on a large scale. For this, the cultivation practice needs to be scaled up.
\end{abstract}

Keywords: Aegopodium alpestre; extraction; microelements; vitamins; amino acids; medicinal plant

\section{Introduction}

Why is it important to find new medicinal plants?

Medicinal plants have proven to be a valuable source of molecules with therapeutic potential. Today, they are crucial for the discovery of new drugs (Atanasov et al., 2015). To create a stable supply of new herbal medicines, researchers should draw their attention to pharmacopoeial, vicarious and the promising species of plants (Grudzinskaya et al., 2014). Aegopodium alpestre is one of those species. 


\section{General characteristics of the genus Aegopodium and the species A. alpestre}

Aegopodium Linnaeus, 1753 is a perennial plant from the family Apiaceae growing in the mountainous regions of Europe, Siberia, the Caucasus, Kazakhstan and Central Asia. The genus Aegopodium includes 8 species: Aegopodium tadshikorum Schischk., A. podagraria L., A. latifolium Turcz., A. kashmiricum (R.R. Stewart ex Dunn) Pimenov, $A$. henryi Diels, $A$. handelii H. Wolff, $A$. burttii Nasir, $A$. alpestre Ledeb. (The Plant List, n.d.). However, only $A$. podagraria and $A$. alpestre are native to Kazakhstan.

A. alpestre creates a ground cover that is sparser as compared to that of $A$.podagraria, (Stukalyuk, 2016). It grows in conifer and mixed forests, mountain meadows, and shrub thickets. A. alpestre reproduces asexually from rhizomes, whilst its sexual mode of reproduction is suppressed. It is a melliferous plant, well eaten by the livestock animals.

\section{Medical applications of ethanol-based extracts of $A$. alpestre}

The medicinal properties of plants in the genus A. are well known. For instance, they have systemic, detoxification, and antihypoxic impact on the human body. Medicines that are made from these plants help improve metabolism and the overall health of the person taking it. Normally, this kind of medicine is a prescription for hypovitaminosis and iron deficiency anemia (Gridneva and Khanina, 2005). Galenicals from the aerial parts of $A$. alpestre are able to improve the kidney function and the renal blood flow. A plant containing such a variety of vitamins, amino acids, and other useful substances is a good candidate for medicinal plant research.

The liquid herbal extract of $A$. alpestre is applied in the treatment of rheumatism, whilst herbal infusions made from its parts are used as headache pain relievers. The available literature knows cases where $A$. alpestre was used in cancer medication (Grudzinskaya et al., 2014).

\section{Chemical composition of plants in the genus Aegopodium}

The chemical composition of different parts of $A$. podagraria has been little studied. The plant was found to contain carbohydrates (i.e., umbelliferose, glucose, and fructose), cyclitols (e.g., glucinol), lectins, secondary metabolites (coumarins such as umbelliferone, bergapten, and methoxsalen; and steroids such as $\beta$ sitosterol), and choline. The aerial part of the plant contains vitamin $\mathrm{C}$, carotene, and flavonoids (quercetin and kempferol). Amino acids found in A. podagraria include arginine, histidine, leucine, lysine, threonine, valine, and methionine. The plant accumulates a variety of micronutrients such as calcium, iron, silicon, phosphorus, magnesium, aluminum, molybdenum, vanadium, copper, gallium, boron, titanium, and zinc. The lipophilic essence of the plant contains $1.5 \%$ of chlorophyll. You may also find unsaturated and saturated fatty acids, such as palmitic, stearic, oleic, linoleic, and arachidic. Furthermore, A. podagraria comprises organic acids in its leaves and steam, such as malic and citric (Tovchiga et al., 2006).

\section{The state-of-the-art and relevance of the study}

Issues addressed by different studies embrace the ecological characteristics, abundance, and role of $A$. alpestre in mountain ecosystems (Wu et al., 2016; Yang et al., 2016). Separate studies examine morphology of the fruits and seeds of the $A$. alpestre with the scanning electron microscopy technique (Ostroumova, 2018), and only one work explores the lipid and vegetable oil content in the seeds of plant specimens belonging to different families, including Apiaceae (Azimova et al., 2012).

Although $A$. alpestre. is widely used in folk medicine, the plant is very little studied. There are no works devoted to the chemical composition of different plant parts of $A$. alpestre. There are no studies examining the content of more complex compounds such as vitamins and amino acids. At the same time, there is a need to find new medicinal plants for the creation of new drugs. A. alpestre may be one of those plants. Although there are studies exploring the morphological and ecological characteristics of $A$. alpestre, phytochemical properties of this plant species remain understudied. If the content of inorganic compounds, vitamins and amino acids is high, $A$. alpestre can be recommended for pharmaceutical purposes. Thus, the aim of this work is to examine 
the phytochemical characteristics of $A$. alpestre using a batch of plants collected in Kazakhstan. The objectives of the study are (1) to measure the concentration of micro- and macro-elements in the leaves and stems of $A$. alpestre, and (2) to establish the concentration of coumarins, flavonoids, vitamins and amino acids in the leaves and stems of $A$. alpestre.

\section{Materials and Methods}

\section{Research object}

The study examines the shoot system of Aegopodium alpestre Ledeb., plant in the genus genus Aegopodium (family Apiaceae). Samples of $A$. alpestre were collected during the period of flowering (early July) in 2018 in the Big Almaty Gorge (latitude/longitude: 43.136976, 76.903267; 1.500-2.500 m a.s.l.) and identified by scientists of the Institute of Botany and Phytointroduction, Ministry of Education and Science (Republic of Kazakhstan). Plant identification was performed through comparing visual characteristics with those indicated in (Baitenov, 2001).

\section{Methods}

For the morphological analysis, leaves and stems were collected, dried, and pressed. Leaf and stem samples were conserved according to Strasburger-Fle $u$ ming method using a 1:1:1 mixture of alcohol-glycerinwater.

Anatomical slides preparation of leaves and stems was performed using an electronic microtome MZP01 Technom. A total of 106 temporary anatomical slides with 10-15 $\mu \mathrm{m}$ thickness were prepared and then placed into glycerol and balsam (Barykina et al., 2004; Yeung et al., 2015). Microphotographs were obtained with a video microscope MCX100 Trinocular MICROS (magnification x100, x400; Austria).

A total of 1200 samples were collected from 300 plants. One sample contained all the leaves or stems from one plant. Hence, there were four samples ( 2 with leaves and 2 with stems) per plant, which were tested for the presence of inorganic and organic compounds.

\section{Methods of extraction and spectrophotometry}

Moisture and ash content and extractivity of raw materials were estimated according to requirements of the State Pharmacopoeia of the Republic of Kazakhstan and the European Pharmacopoeia (Council of Europe, 2001; Tulegenova, 2008, 2009).

To determine the weight loss on drying, a certain amount of raw material was placed in an oven heated to $105^{\circ} \mathrm{C}$

The content of inorganic compounds was determined by measuring inorganic mass that has remained after the incineration and calcination of pre-prepared raw material. For this, $1 \mathrm{~g}$ of biomass (either leaves or stems) was placed in a crucible for charring. The crucible with a charred sample was then placed into a laboratory muffle furnace. The furnace temperature was held at $550^{\circ} \mathrm{C}$ until complete calcination. After calcination, the crucible was allowed to cool down for 2 hours and then placed in a flaw detector, which contained anhydrous calcium chloride at its bottom. Finally, sample was cooled down and weighed on a balance.

To determine the content of organic compounds, samples were crushed and passed through a sieve with an opening diameter of $1 \mathrm{~mm}$. One gram of the resulting biomass was placed in a conical flask and added 50 $\mathrm{cm} 3$ of $80 \%$ ethanol. The flask was then closed with a lid. The sample was weighed on a balance with a weighing error of up to $0.01 \mathrm{~g}$ and kept intact for 1 hour. Afterwards, the collector was connected to a reverse condenser. The content of the flask was heated until boiling and maintained for 2 hours. When cooled down, the flask was again covered with a lid and weighed. The weight gap was closed with ethanol. The content of the flask was filtered through a paper filter and the filtrate volume was $25 \mathrm{~cm} 3$. The sample was heated in a water bath. After 
evaporation, the content of the flask was dried at $105^{\circ} \mathrm{C}$ for 3 hours and then cooled down for 30 minutes in a desiccator with dehydrated calcium chloride at the bottom. The final weigh was taken afterwards.

All tests were conducted in triplicate.

The content of flavonoids, secondary metabolites (coumarins), vitamins, macro-and microelements and amino acids was determined by spectrophotometry, high-performance liquid chromatography (HPLC), and gas chromatography/mass spectrometry (GC/MS).

\section{Data analysis}

Normally distributed data were analyzed in Past v. 3.0. Differences were determined using a two-sample $\mathrm{t}$-test with a significance level of 0.05 . Tables provide information about the mean values and standard errors (mean \pm SEM).

\section{Results}

\section{Morphological properties}

Aegopodium alpestre Ledeb. is a perennial grassy plant, growing to a height of $69.13 \pm 14.8 \mathrm{~cm}$ with rhizomes. The stem is hollow, furrowed, simple or slightly branching at the top. Both sides of the leaves are glabrous. Lower leaves are petiolate (attached to the stem by a petiole), and upper leaves are sessile (attached directly to the stem, lacking a petiole). The plates of lower leaves in the outline are broadly triangular, almost threefold; segments of its pinnate are dissected into ovate, pointed, incised-dentate lobes, about $3 \mathrm{~cm}$ long. The upper leaves have the lobes lanceolate and sharp. A compound umbel has 15 to 20 rays (floral branches), without involucres and involucels. These rays are angular, and the outer rays are much longer than the inner ones. The flower petals are $1 \mathrm{~mm}$ long, without clear tubules (Figure 1).

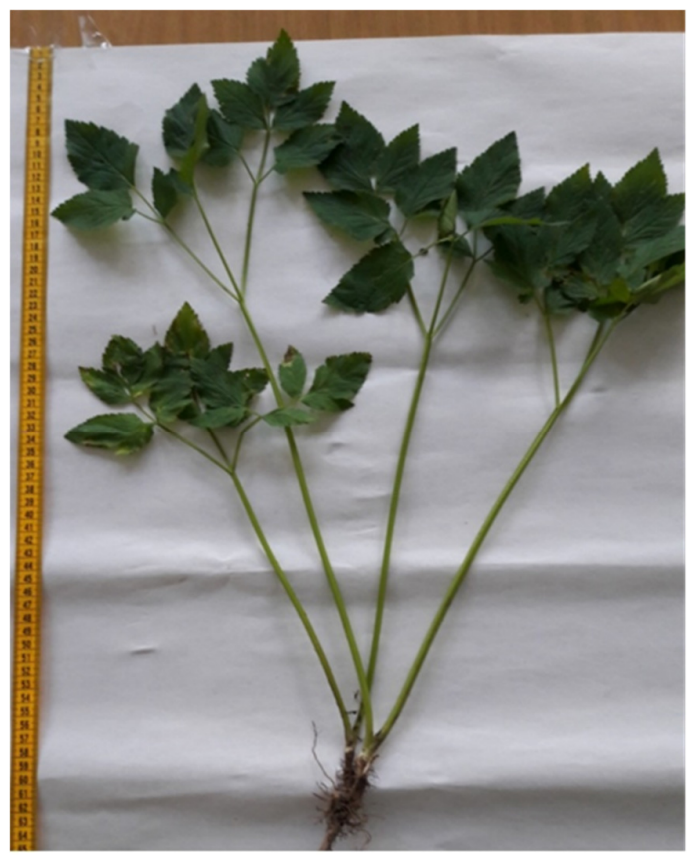

Figure 1. Aegopodium alpestre Ledeb

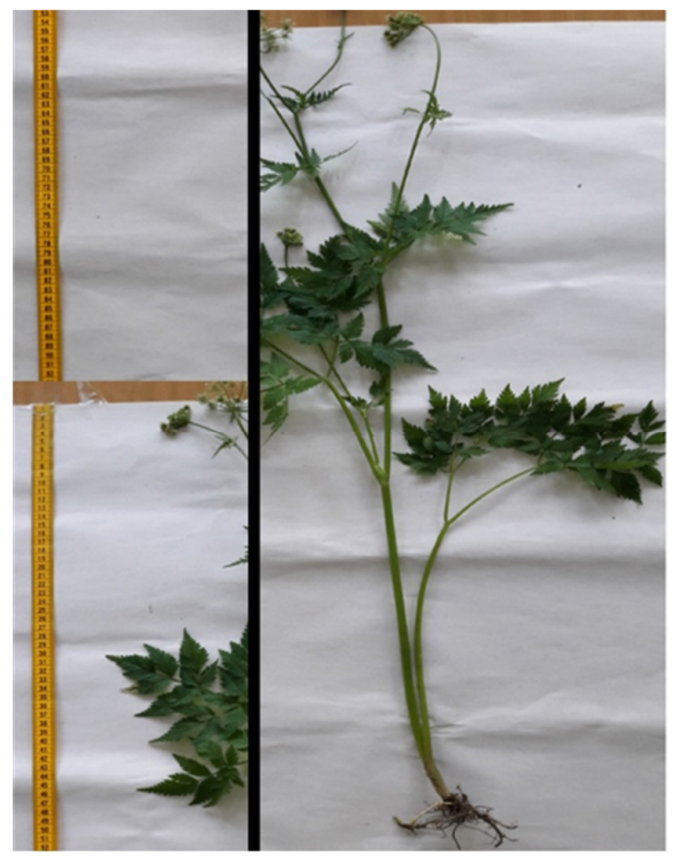




\section{Anatomical properties}

The cross-section of the stem is ribbed; it consists of primary cortex and central cylinder. Steam thickness is $5630.77 \pm 0.31 \mu \mathrm{m}$, and epidermal thickness is $37.61 \pm 0.70 \mu \mathrm{m}$. Under the epidermis, parenchyma cells with thickened walls are located. In the ribs of the stem, collenchyma cells can be found, arranged in eight rows (Figure 2).

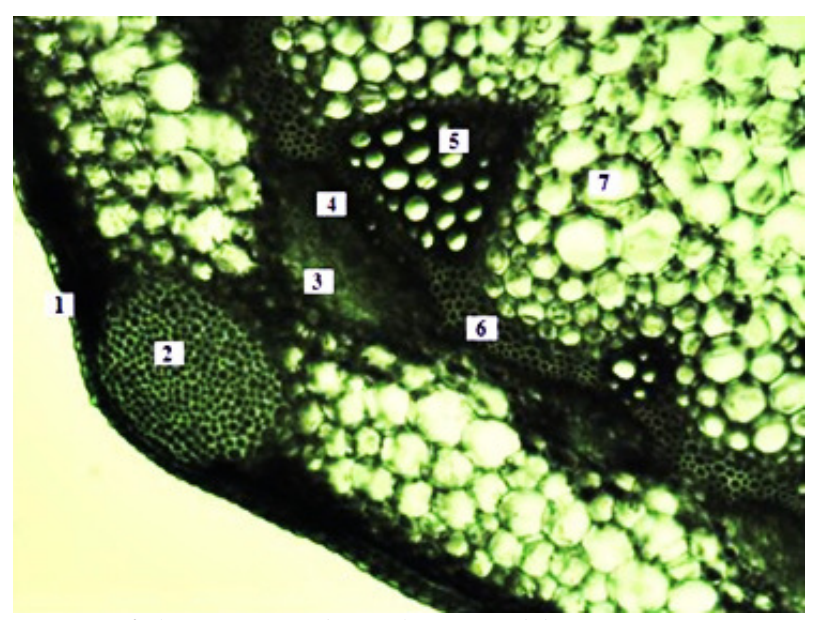

Figure 2. Internal structure of plant Aegopodium alpestre Ledeb.

${ }^{*}$ Note: 1 - epidermis, 2 - collenchyma, 3 - bast fibers, 4 - phloem, 5 - xylem, 6 interfascicular vascular cambium, 7 parenchyma

As a characteristic of dicotyledonous plants, the intercellular cambium forms a ring. In the center of the stem, an air cavity is located. In seed plants, conductive bundles are typically collateral, the xylem is located adaxially, and the phloem is positioned abaxially. The number of conductive bundles in the stem is 28 ; they form in different sizes, with the maximum phloem thickness of $52.41 \pm 0.40 \mu \mathrm{m}$, and the maximum xylem thickness $335.75 \pm 0.37 \mu \mathrm{m}$ (Table 1). On the outside, the conductive bundles are surrounded by sclerenchyma.

Table 1. The $A$. alpestre stem parameters

\begin{tabular}{|c|c|c|c|c|c|}
\hline \multirow[t]{2}{*}{ Stem thickness, $\mu \mathrm{m}$} & \multirow[t]{2}{*}{ Collenchyma, $\mu \mathrm{m}$} & \multirow[t]{2}{*}{ Bast fibre, $\mu \mathrm{m}$} & \multirow{2}{*}{$\begin{array}{l}\text { Epidermis, } \\
\text { Mm }\end{array}$} & \multicolumn{2}{|c|}{$\begin{array}{l}\text { Conductive bundle thickness } \\
\qquad(\max ), \mu \mathrm{m}\end{array}$} \\
\hline & & & & Xylem & Phloem \\
\hline $5630.77 \pm 0.31$ & $560.83 \pm 0.38$ & $142.35 \pm 0.36$ & $37.61 \pm 0.70$ & $335.75 \pm 0.37$ & $52.41 \pm 0.40$ \\
\hline
\end{tabular}

Leaves of $A$. alpestre in a cross-section consist of the upper and lower epidermis, mesophyll, conductive bundles, and cells of mechanical tissue. Cells of the upper and lower epidermal layers come in different quantities, shapes, and sizes. Hence, the upper-layer cells are larger $(97.08 \pm 1.4 \mu \mathrm{m})$ compared to cells of the lower epidermis $(52.41 \pm 0.70 \mu \mathrm{m})$. The palisade cell layer of mesophyll is thin, which is characteristic of shade plants. The thickness of the central vein is $2493.38 \pm 1.37 \mu \mathrm{m}$. The central conductive bundle is large, with the length of $471.20 \pm 3.0 \mu \mathrm{m}$, collateral, surrounded by sclerenchyma cells. The xylem is located on the upper side of the leaf plate and the phloem is located on the bottom side, both are well developed (Figure 3).

\section{Phytochemical analysis}

Data in Table 2 show high extractivity of leaves and stems (28.77\% and $25.44 \%$, respectively). Perhaps, this is due to a high concentration of organic compounds. The quantitative content of basic biologically active substances in the above the ground vegetative organs of $A$. alpestre is depicted in Table 3. 


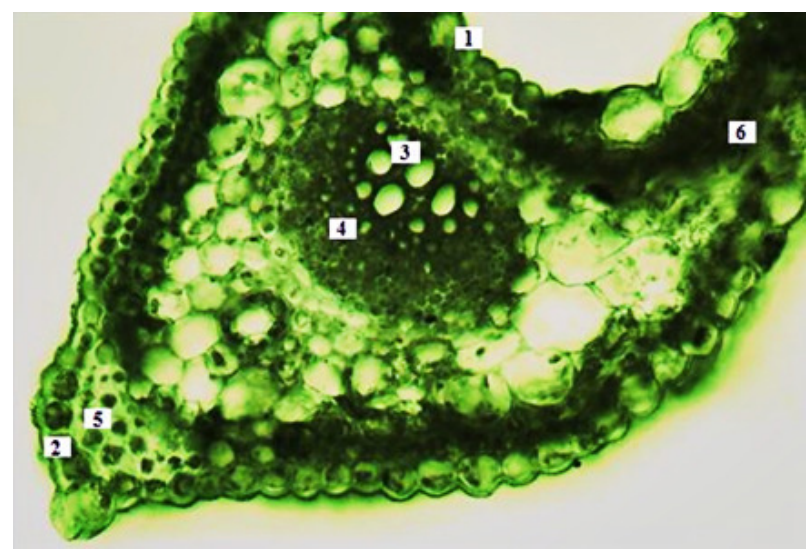

Figure 3. Internal structure of the Aegopodium alpestre leaves.

*Note: 1 - upper epidermis, 2 - lower epidermis, 3 -xylem, 4 - phloem, 5 - collenchyma, 6 - spongy mesophyll

Table 2. Parameters of good-quality raw materials from Aegopodium alpestre

\begin{tabular}{|c|c|c|}
\hline \multirow{2}{*}{ Indicator } & \multicolumn{2}{|c|}{ Item } \\
\cline { 2 - 3 } & Leaf & Stem $^{1}$ \\
\hline Moisture content & $6.33 \%^{1}$ \\
\hline Ash content & $16.15 \%$ & $27.9 \%$ \\
\hline Extractivity & $28.77 \%$ & $25.44 \%$ \\
\hline
\end{tabular}

${ }^{1}$ - Differences were considered significant at $\mathrm{p} \leq 0.05$.

Table 3. Content of biological active substances in Aegopodium alpestre

\begin{tabular}{|c|c|c|}
\hline \multirow{2}{*}{ Indicator } & \multicolumn{2}{|c|}{ Item } \\
\cline { 2 - 3 } & Leaf & $0.25 \%$ \\
\hline Coumarins & $0.32 \%$ & $0.34 \%$ \\
\hline Flavonoids & $0.77 \%$ & $9.7 \%$ \\
\hline Mass fraction of carbohydrates & $6.99 \%$ & $2.84 \%$ \\
\hline Mass fraction of protein & $3.5 \%$ & $0.86 \%$ \\
\hline Tannin & $4.25 \%$ & \\
\hline
\end{tabular}

Data in Table 3 show that the content of coumarins in the leaves of $A$. alpestre $(0.32 \%)$ is higher by $0.25 \%$ than that in the stems $(\mathrm{p} \leq 0.05)$. There are two times as many flavanoids in leaves as in stems $(0.77 \% \mathrm{vs}$ $0.34 \% 6 \mathrm{p} \leq 0.01)$. The content of carbohydrates is also high. Leaves contain $6.99 \%$ of carbohydrates and stems contain $9.7 \%$ of carbohydrates ( $\mathrm{p} \leq 0.05)$. Protein content in leaves and stems is $3.5 \%$ and $2.84 \%(\mathrm{p} \leq 0.05)$, respectively. Tannin content in leaves is almost five times higher than that in stems $(4.25 \%$ vs $0.86 \%, p \leq 0.01)$. The content of heavy metal Cd is within the range permissible for medicinal plants (Table 4).

Table 4. Findings from the elemental composition analysis

\begin{tabular}{|c|c|c|c|}
\hline \multirow{2}{*}{ Element } & \multicolumn{2}{|c|}{ Concentration, mg per $100 \mathrm{~g}$} & \multirow{2}{*}{ Value } \\
\cline { 2 - 4 } & Leaf & Stem & Microelement \\
\hline Iron, Fe & 12.973 & 3.144 & Microelement \\
\hline Copper, Cu & Not detected & Not detected & Microelement \\
\hline Zinc, Zn & 7.138 & 3.619 & Heavy metal \\
\hline Cadmium, Cd & 0.00004 & 0.00024 & Microelement \\
\hline Calcium, Ca & Not detected & Not detected & Microelement \\
\hline Potassium, $\mathrm{K}$ & 0.0387 & 0.0110 & Microelement \\
\hline Phosphorus, P & 87.63 & 67.37 & Microelement \\
\hline Selenium, Se & 0.010 & 0.019 & \\
\hline
\end{tabular}


From the data presented in Table 4, it can be seen that vegetative organs of $A$. alpestre have a sufficient quantity of phosphorus, iron and zinc. The phosphorus content in leaves $(87.63 \mathrm{mg}$ per $100 \mathrm{~g})$ is 1.3 times higher than that in stems $(67.37 \mathrm{mg}$ per $100 \mathrm{~g}, \mathrm{p} \leq 0.05)$. Iron content is four times higher $(12.973 \mathrm{vs} 3,144 \mathrm{mg}$ per $100 \mathrm{~g}, \mathrm{p} \leq 0.01$ ) and zinc content is two times higher ( 7.138 vs $3,619 \mathrm{mg}$ per $100 \mathrm{~g}, \mathrm{p} \leq 0.05)$. Leaves and stems have a similar quantity of selenium, which belongs to a group of essential trace elements $(0.010 \mathrm{vs} 0.019$ mg per $100 \mathrm{~g}$ ). Here, the following five vitamins were detected: B6, C, B3, B5, and Bc. Ascorbic acid (vitamin C) and the vitamin B3 (pantothenic xylitol) were found in large quantities: 79.0 and $32.0 \mathrm{mg}$ per $100 \mathrm{~g}$, respectively (Table 5).

Table 5. Vitamins and their concentration in the Aegopodium alpestre Ledeb. plant samples

\begin{tabular}{|c|c|c|}
\hline Vitamins, $m$ g per 100 $\mathbf{g}$ & Leaf & Stem \\
\hline $\mathrm{B}_{6}$ (pyridoxine) & 18.0 & 14.0 \\
\hline $\mathrm{C}$ (ascorbic acid) & 79.0 & 31.0 \\
\hline $\mathrm{B}_{3}$ (pantothenic xylitol) & 32.0 & 4.00 \\
\hline $\mathrm{B}_{5}$ (nicotinic xylitol) & 53.0 & 11.0 \\
\hline $\mathrm{B}_{\mathrm{c}}$ (folic acid xylitol) & 24.0 & 11.0 \\
\hline
\end{tabular}

Table 5 shows that leaves pack more vitamins than stems. For instance, leaves contain 1.3 times more pyridoxine, 2.5 times more ascorbic acid ( $\mathrm{p} \leq 0.05), 8$ times more pantothenic acid, 4.8 times more nicotinic acid $(\mathrm{p} \leq 0.01)$, and almost 2 times more folic acid $(\mathrm{p} \leq 0.05)$.

$A$. alpestre is comprised of 13 amino acids, which may be found in its leaves and stem. Of those, only eight are indispensable. The percentage of essential amino acids from the total amino acids is $59.29 \%$ in leaves and $54.11 \%$ in stems (Table 6).

Table 6. Amino acids and their proportion in the Aegopodium alpestre Ledeb. plant samples

\begin{tabular}{|c|c|c|}
\hline \multirow{2}{*}{ Amino acids } & \multicolumn{2}{|c|}{ Mass fraction (mg \%) } \\
\cline { 2 - 3 } & Leaf & Stem \\
\hline Arginine $^{*}$ & $1.14 \pm 0.46$ & $0.26 \pm 0.10$ \\
\hline Lysine $^{*}$ & $0.66 \pm 0.22$ & $0.14 \pm 0.05$ \\
\hline Tyrosine $^{*}$ & $0.37 \pm 0.11$ & $0.14 \pm 0.04$ \\
\hline Phenylalanine $^{*}$ & $0.66 \pm 0.20$ & $0.04 \pm 0.02$ \\
\hline Histidine $^{*}$ & $0.23 \pm 0.12$ & $0.22 \pm 0.06$ \\
\hline Leucine + isoleucine $^{*}$ & $1.05 \pm 0.27$ & $0.19 \pm 0.08$ \\
\hline Valine $^{*}$ & $0.77 \pm 0.31$ & $0.56 \pm 0.15$ \\
\hline Proline $^{*}$ & $1.16 \pm 0.30$ & $0.26 \pm 0.10$ \\
\hline Threonine & $0.15 \pm 0.04$ \\
\hline Serin & $0.85 \pm 0.34$ & $0.16 \pm 0.04$ \\
\hline Alanin & $0.64 \pm 0.17$ & $0.14 \pm 0.05$ \\
\hline Glycine & $0.74 \pm 0.19$ & 2.31 \\
\hline Total amino acids & $0.77 \pm 0.26$ & 1.25 \\
\hline Essential amino acids & 9.04 & 54.11 \\
\hline The proportion of essential amino acids & 5.36 & \\
\hline in total amino acids, $\%$ & 59.29 & \\
\hline & ${ }^{*}$ Essential amino acids & \\
\hline
\end{tabular}

Table 6 demonstrates that the content of amino acids is higher in leaves than in stems. Thus, arginine content in leaves is 4.4 times higher than that in stems; lysine content is 4.7 times higher; and tyrosine content is 7.4 times higher than that in stems $(\mathrm{p} \leq 0.01)$. Leaves contain 4.7 times more phenylalanine, 5.7 times more histidine; and 4.7 times more leucine + isoleucine $(\mathrm{p} \leq 0.01)$. The content of valine in leaves is 4 times higher than that in stems. Leaves comprise two times more proline and 3.3 times more threonine than stems $(\mathrm{p} \leq$ 
$0.01)$. The serine content in leaves is 4.3 times higher than that in stems. The alanine content is 4.6 times higher than that in stems. Finally, glycine content is 5.5 times higher than that in stems $(\mathrm{p} \leq 0.01)$.

\section{Discussion}

A. alpestre does not cover large areas with dense stands. On the contrary, one can find $A$. alpestre growing either singly or in small groups (Ilyas et al., 2018). The habitat of this particular plant species is hardly accessible and is located high in the mountains such as the Tien Shan Mountains and the Alatau Mountains (Yang et al., 2016; Nesterova et al., 2018). Hence, plant pickers will be not able to gather $A$. alpestre in large quantities. Thus, due to inaccessibility of habitats and low plant density per unit area, the economic feasibility of collecting $A$. alpestre in the wild is rather low compared to industrial-scale cultivation.

There are no studies on medicinal properties of $A$. alpestre. Yet, there are three research papers devoted to the chemical composition of this plant's roots and seeds (Sun, 2009; Zhu et al., 2010; Azimova et al., 2012). Authors of the first study found a higher concentration of volatile oils and related compounds in the $A$. alpestre than in $A$. podagraria (i.e., $3.12 \%$ vs $0.04 \%$ and $0.14 \%$ in seeds and fruits, respectively) (Azimova et al., 2012). This indicates that $A$. alpestre is of great value as a medicinal plant. Other studies focus more on a detailed analysis of seeds and roots in terms of composition (Sun, 2009; Zhu et al., 2010). In particular, it was found that seeds of the $A$. alpestre contain 18 substances (in the essential oil), among which apiol with the proportion of $59 \%$ as well as undecane (19\%) and limonene (5\%). While these results were obtained by supercritical extraction, the second method (i.e., steam distillation) revealed 14 substances, among which apiol (21\%), undecane (41\%), $\beta$-fellandren (7\%), and lemonene (13\%). These two approaches have provided slightly different results, although the overall composition of the substances is approximately the same (Sun, 2009). Another, this time Chinese study made it possible to establish the most optimal parameters for the extraction of oils from raw materials (water-to-raw materials ratio, 2.75 to 1.0 ; temperature, $71{ }^{\circ} \mathrm{C}$; extraction duration, 2.0 hours) (Zhu et al., 2010). The calculated extraction rate was $19.2 \%$.

Note that these few results relate to the seeds but not to other parts of the plant like stems and leaves. This article is first to display the high concentration and diversity of vitamins (6 types), micronutrients (5 types), and aminoacids (13 types) in the leaves and steams of $A$. alpestre.

In this study, the height of collected plants was $69.13 \pm 14.8 \mathrm{~cm}$. Since the layer of palisade cells in these plants is thin, they can be argued shade-tolerant. By contrast, the stem contains 28 well-developed conductive bundles.

The chemical analysis revealed high extractivity of $A$. alpestre and higher concentration of certain biologically active substances (e.g., flavanoids, coumarins, tannins, carbohydrates, and proteins) in leaves compared to stems. The plant produces 8 essential amino acids and a large quantity of vitamins. The concentration of heavy metals falls within the normal range.

\section{Conclusions}

It was established that $A$. alpestre has a significant concentration of vitamins, microelements and other substances. Hence, it can be recommended for the production of vitamin and mineral complexes. The medicinal effect of $A$. alpestre requires further investigation. The present findings conclude that identification of biologically active substances in the above the ground vegetative organs of $A$. alpestre may be a common practice in the future. Considering the study results, $A$. alpestre may be used as a medicinal plant on a large scale. For this, the cultivation practice needs to be scaled up. 


\section{Authors' Contributions}

Conceptualization: AS and SS; Data curation: NS and KA; Formal analysis: EK and GZ; Funding acquisition: EI; Investigation: EI and SS; Methodology: AS and KA; Project administration: NS and SS; Resources: GZ and KA; Software: AS; Supervision: EK; Validation: GZ; Visualization: EK; Writing - original draft: EI; Writing - review and editing: NS.

\section{Acknowledgements}

This research received no specific grant from any funding agency in the public, commercial, or not-forprofit sectors.

\section{Conflict of Interests}

The authors declare that there are no conflicts of interest related to this article.

\section{References}

Atanasov AG, Waltenberger B, Pferschy-Wenzig EM, Linder T, Wawrosch C, Uhrin P, ... Stuppner H (2015). Discovery and resupply of pharmacologically active plant-derived natural products: A review. Biotechnology Advances 33(8):1582-1614. https://doi.org/10.1016/j.biotechadv.2015.08.001

Azimova SS, Glushenkova AI, Vinogradova VI (2012). Lipids, Lipophilic components and essential oils from plant sources. New York, Springer.

Baitenov MC (2001). Flora of Kazakhstan. Almaty, Gylym.

Barykina RP, Veselova TD, Devyatov AG, Dzhalilova HH, Ilyina GM, Chubatova NV (2004). Handbook of botanical microtechnique. Basicsand methods. Moscow, MGU Publishers.

Council of Europe (2001). European pharmacopoeia. NSO (3rd ed), Strasburg.

Gridneva ES, Khanina MA (2005). Microscopic investigation over the promising medicinal plants of the Siberian flora. In: Anniversary collection of research papers dedicated to the 30th Anniversary of the Pharmaceutical Faculty of the Altai Medical University, Barnaul, pp 66-72.

Grudzinskaya LM, Gemedzhieva NG, Nelina NV, Karzhaubekova ZhZ (2014). Annotated list of medicinal plants in Kazakhstan: Reference edition. Almaty, Institute of Botany and Phytointroduction.

Ilyas M, Qureshi R, Akhtar N, Ziaul-Haq, Mahmood Khan A (2018). Floristic diversity and vegetation structure of the remnant subtropical broad-leaved forests from Kabal Valley, Swat, Pakistan. Pakistan Journal of Botany $50(1): 217-230$.

Nesterova SG, Kokoreva II, Inelova ZA, Yerubayeva GK (2018). Plant biodiversity in Aksay gorge of Trans-Ili Alatau. Acta Zoologica Bulgarica 11:149-153. http://acta-zoologica-bulgarica.eu/downloads/acta-zoologicabulgarica/2018/supplement-11-149-153.pdf

Ostroumova TA (2018). Fruit micromorphology in the Umbelliferae of the Russian Far East. Botanica Pacifica 7(1):4149. https://doi.org/10.17581/bp.2018.07107

Stukalyuk SV (2016). Changes in the structure of ant assemblages in broad-leaved forests with domination of Impatiens parviflora Dc. (Balsaminaceae) in herbaceous layer. Russian Journal of Biological Invasions 7(4):383-395. https://doi.org/10.1134/S2075111716040081

Sun G-R (2009). GC/MS analysis of volatile components from Aegopodium alpestre seeds. Journal of Anhui Agricultural Sciences 1:18-19.

The Plant List (n.d.). Retrieved 2020 May 13 from http://www.theplantlist.org/tpl/search?q=Aegopodium

Tovchiga OV, Stepanova SI, Shtrygol SY (2006). Perspectives of goutweed leaves lipophilic fraction using. Medicinal Chemistry $8(1): 82-83$. 
Tulegenova AU (2008). State Pharmacopoeia of the Republic of Kazakhstan. Zhibek Zholy (vol. I), Almaty. Tulegenova AU (2009). State Pharmacopoeia of the Republic of Kazakhstan. Zhibek Zholy (vol. II), Almaty.

Wu W, Hu Y, Li Y, Gong J, Chen L, Chang Y, Xiong Z (2016). Plant diversity and vegetation structures in the understory of mixed boreal forests under different management regimes. Polish Journal of Environmental Studies 25(4):1749-1750. https://doi.org/10.15244/pjoes/62101

Yang Zh, Zhang Y, Ren H, Yan S, Kong Zh, Ma K, Ni J (2016). Altitudinal changes of surface pollen and vegetation on the north slope of the Middle Tianshan Mountains, China. Journal of Arid Land 8(5):799-810. https://doi.org/10.1007/s40333-016-0085-9

Yeung ECT, Stasolla C, Sumner J, Huang BQ (2015). Plant microtechniques and protocols. New York, Springer.

Zhu N-N, Hou SF, Sun G-R, Guo L (2010). Optimization of polysaccharide extraction from root of Aegopodium alpestre in Changbai Mountain with response surface method. Journal of Beihua University 6:553-558.

OPEN ACCESS

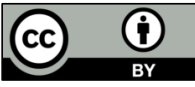

The journal offers free, immediate, and unrestricted access to peer-reviewed research and scholarly work. Users are allowed to read, download, copy, distribute, print, search, or link to the full texts of the articles, or use them for any other lawful purpose, without asking prior permission from the publisher or the author.

License - Articles published in Notulae Botanicae Horti Agrobotanici Cluj-Napoca are Open-Access, distributed under the terms and conditions of the Creative Commons Attribution (CC BY 4.0) License. (c) Articles by the authors; UASVM, Cluj-Napoca, Romania. The journal allows the author(s) to hold the copyright/to retain publishing rights without restriction. 